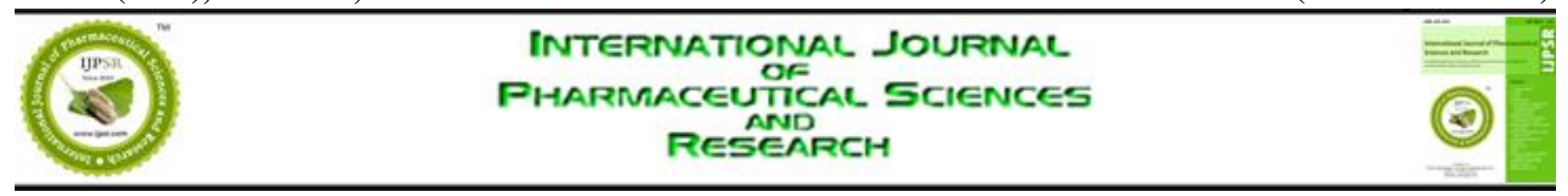

Received on 12 June, 2017; received in revised form, 05 November, 2017; accepted, 26 January, 2018; published 01 March, 2018

\title{
A VALIDATED LC-MS/MS METHOD FOR PHARMACOKINETIC STUDY OF AFATINIB IN HEALTHY RABBITS
}

\author{
Bhetanabotla Chandramowli* and Bigala B. Rajkamal \\ Mewar University, Chittorgarh - 312901, Rajasthan, India.
}

Keywords:

Afatinib, Pharmacokinetics,

LC-MS/MS, Rabit model, Method development, Validation

\section{Correspondence to Author:}

Bhetanabotla Chandramowli

Research Scholar,

Mewar University, Chittorgarh -

312901, Rajasthan, India.

E-mail:bhetanabotlachandramowli@gmail.com

\begin{abstract}
A liquid chromatography-tandem mass spectrophotometric (LCMS/MS) method was developed for quantification of Afatinib in rabit plasma employing Solid Phase Extraction (SPE) technique. Developed method was validated for specificity, precision, accuracy, recovery, and stability characteristics. Chromatographic separation was achieved on Gemini, $5 \mu \mathrm{C} 18$, $50 \times 4.60 \mathrm{~mm}$ with $30: 70 \mathrm{v} / \mathrm{v}$ of $10 \mathrm{mM}$ ammonium acetate in water: Organic Mixture (methanol : acetonitrile, $80: 20 \% \mathrm{v} / \mathrm{v}$ ) as an isocratic mobile phase with a flow rate of $1.0 \mathrm{ml} / \mathrm{min}$. the developed LC-MS method was applied to assess pharmacokinetics parameters of afatinib $(20 \mathrm{mg})$ tablet in healthy rabbits. Six Male albino rabbits weighing $2.0-2.5 \mathrm{~kg}$ were randomly selected for the pharmacokinetic study. The tablets were administered to rabbits using a balling gun. Blood samples $(0.6 \mathrm{ml})$ were withdrawn from the marginal ear vein before dosing (zero time) and at time intervals of $0.5,1,1.5,2,2.5,3,4,5,6,7,8,10$, 12, 20, 24, 36 and $48 \mathrm{hr}$ after administration. Plasma was separated by centrifugation at $5000 \mathrm{rpm}$ for $10 \mathrm{~min}$ and the plasma concentrations of afatinib at different times were determined by LC-MS/MS. Pharmacokinetic parameters was calculated. Afatinib showed $\mathrm{T}_{\max }$ of $3.833 \pm 0.752$ and mean $\mathrm{C}_{\max }, \mathrm{AUCO} \mathrm{O}_{\rightarrow \mathrm{t}}$ and $\mathrm{AUC}_{0 \rightarrow \alpha}$ for Test formulation is $675.83 \pm 22.031,6213.417 \pm 257.922$ and $6474.61 \pm 258.45$ respectively.
\end{abstract}

INTRODUCTION: Afatinib, irreversible tyrosine kinase inhibitor of the ErbB family of receptors and is effective in treating tumors of various types ${ }^{1-7}$. The recommended daily oral dose is $40 \mathrm{mg} / \mathrm{day}$, it can be increased to a maximum of $50 \mathrm{mg} /$ day, or decreased to a minimum of $20 \mathrm{mg} / \mathrm{day}$, depending on tolerability $^{8-9}$. The preclinical pharmacokinetics and metabolism of afatinib were studied in several animal species (mice, rats, rabbits and Go"ttingen minipigs). In all species, metabolism was minimal; excretion of unchanged parent compound accounted for $>50,>60,>72$, and $>87 \%$ in the rat,

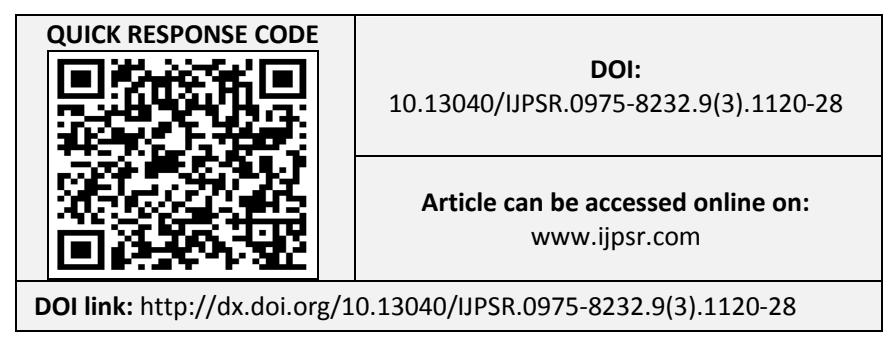

Mouse, minipigs and rabbit, respectively (Boehringer Ingelheim, unpublished data) ${ }^{10-11}$. To characterise the clinical pharmacokinetics of afatinib in a large number of patients with advanced solid tumours, a meta-analysis of five phase I trials and one phase II trial in patients with advanced solid tumours $(n=221)$ who received afatinib (10 - $100 \mathrm{mg}$ doses) was performed using non-compartmental analysis ${ }^{12-17}$.

In an another study it was found that Mild to moderate hepatic impairment had no clinically relevant effect on the pharmacokinetics of a single $50 \mathrm{mg}$ dose of afatinib $^{18}$. Few LC-MS/MS methods were reported for human pharmacokinetic studies of afatinib alone ${ }^{19}$ or in combination ${ }^{20}$ with other drugs. In patients with solid tumors, Tmax of afatinib occur approximately 2 - $5 \mathrm{hr}$ after oral dosing and decline afterwards in an at least biexponential manner. 
Afatinib metabolism is minimal and the unchanged drug predominantly excreted in the faeces and approximately 5\% in urine. (Boehringer Ingelheim, unpublished data) ${ }^{8,10}$. The affinity of afatinib in binding with haemoglobin covalently results decreased plasma concentration levels ${ }^{8}$. Hence it is essential to develop more sensitive analytical methods to determine the concentration of afatinib from plasma samples. To best of our knowledge, no published LC-MS/MS based methods for pharmacokinetic study of afatinib in healthy rabbits. Therefore a liquid chromatography-tandem mass spectrophotometric (LC-MS/MS) method was developed, validated and applied for quantification of Afatinib in rabit plasma employing Solid Phase Extraction (SPE) technique. The established LLOQ is sufficiently low to conduct a pharmacokinetic study with any marketing formulation of afatinib in human volunteers.

\section{Experiment:}

Apparatus and Software: The HPLC system with an auto sampler was a Shimadzu LC- 20A Dvp (Shimadzu, Japan) coupled with Applied Biosystem Sciex (MDS Sciex, Canada) API 4000 Tandem mass spectrometer. The auto sampler was SIL-HTC from Shimadzu, Japan. The solvent delivery module was LC-20AD from Shimadzu, Japan. The chromatographic integration was performed by Analyst software (version: 1.4.2; Applied Biosystems).

Chemicals and Reagents: Afatinib and Afatinib D3 (IS) were procured from Unichem Laboratories Ltd., Mumbai, India, ammonium acetate was procured from Merck Specialities Pvt. Ltd., Mumbai, India. Water used was collected from water purification systems (Milli Q, Milli Pore, USA) installed in laboratory. Methanol and acetonitrile were of HPLC grade and were supplied by J. T. Baker, USA. Hyderabad. The study was approved by Institutional Ethical committee no: VCP/IAEC/2016-44.

Calibration standard Solutions: Stock solutions of Afatinib and Afatinib D3 internal standard (IS) were prepared in methanol. Further dilutions were carried out in $70 \%$ methanol. Calibration standards of eight concentration levels were prepared freshly by spiking drug free plasma with Afatinib stock solution to give the concentrations of $2.00,4.00$, 20.00, 40.0, 80.0, 160, 300 and $600 \mathrm{ng} / \mathrm{ml}$.

Quality Control Standards: Lowest quality control standards, Median quality control standards and highest quality control standards were prepared by spiking drug free plasma with Afatinib to give solution containing 6,240 and $480 \mathrm{ng} / \mathrm{ml}$ respectively. They were stored at $-200 \mathrm{c}$ till the time analyzed.

Chromatographic Conditions: Chromatographic separation was performed on a Gemini, $5 \mu \mathrm{C} 18,50$ $\times 4.60 \mathrm{~mm}$ with $30: 70 \mathrm{v} / \mathrm{v}$ of $10 \mathrm{mM}$ ammonium acetate in water: Organic Mixture (methanol: acetonitrile, $80: 20 \% \mathrm{v} / \mathrm{v}$ ) as an isocratic mobile phase with a flow rate of $1.0 \mathrm{ml} / \mathrm{min}$. Injection volume was $5 \mu \mathrm{l}$. Total analysis time of single injection was 2.00 minutes. Column oven temperature and auto sampler temperature was set to $40{ }^{\circ} \mathrm{C}$ and $5{ }^{\circ} \mathrm{C}$, respectively.

Mass Spectrometric Conditions: The LC eluent was split (75\%), and approximately $0.25 \mathrm{ml} / \mathrm{min}$ was introduced and Quantitation was achieved with MS/MS detection in negative ion mode for the analytes and IS using a MDS Sciex API-4000 mass spectrometer (Foster City, CA, USA) equipped with Turboion spray ${ }^{\mathrm{TM}}$ interface at $400{ }^{\circ} \mathrm{C}$. The ion spray voltage was set at $5500 \mathrm{~V}$. The source parameters viz., the nebulizer gas, curtain gas, CAD gas were set at 40, 40 and 5 psi, respectively. The compound parameters viz. the declustering potential (DP), collision energy (CE), entrance potential (EP) and collision cell exit potential (CXP) for MT and MT-D3 were similar and are $55,-25,-10,-6 \mathrm{~V}$. For Afatinib and Afatinib D3 the DP, CE, EP and CXP were -55, -24, -10 and $18 \mathrm{~V}$. A Turbo ion spray interface (TIS) operated in negative ionization mode was used for the detection. Detection of the ions was carried out in the multiple-reaction monitoring mode (MRM), by monitoring the transition pairs of $m$ transitions of $\mathrm{m} / \mathrm{z} \quad 344.10 / 194.00$ for Afatinib and $\mathrm{m} / \mathrm{z}$ 347.30./197.00 for Afatinib D3. Quadrupoles Q1 and Q3 were set on unit resolution.

Study Design: Six Male albino Rabbits (weighing about $2.5 \mathrm{~kg}$ ) were selected as the animal model. The age of the rabbits was $8-12$ weeks. The Rabbits selected for the study had no medication for two weeks prior to the study. Twelve hours 
before drug administration, food was withdrawn from the rabbits until $24 \mathrm{hr}$ post-dosing, while, water was available for rabbits throughout the study. The tablets were administered to rabbits using a balling gun. Blood samples $(0.6 \mathrm{ml})$ were withdrawn from the marginal ear vein before dosing (zero time) and at time intervals of 0.5 , $1,1.5,2,2.5,3,4,5,6,7$ 8, 10, 12, 20, 24, 36, $48 \mathrm{hr}$ after administration. For each animal the total number of blood samples drawn during the study was 17. EDTA disodium salt was used as an anticoagulant. Plasma was separated by centrifugation at $5000 \mathrm{rpm}$ for $10 \mathrm{~min}$ and the resulting plasma sample from each blood sample was divided into two aliquots and stored in suitably labeled polypropylene tubes at $-20{ }^{\circ} \mathrm{C}$ until used. All the plasma samples were analysed under the construction of standard calibration curve of afitanib in rabbit's plasma. The afatinib concentrations in the rabbit plasma samples was calculated using the calibration curve, obtained after linear regression of the peak area ratio (afitanib/afitinib-D3) versus the concentration of afitinib.

Sample Preparation Method: To 200 $\mu 1$ of plasma, $50 \mu \mathrm{l}$ of Afatinib D3 $(1 \mu \mathrm{g} / \mathrm{ml})$ was added and vortexed. Add $200 \mu \mathrm{L}$ of Extraction buffer (0.1N Sodium hydrogen Carbonate in water) to all samples and vortex for about 30 seconds. Centrifuge all samples at 4000rpm for 2 minutes by using refrigerated centrifuge maintained at $10 \pm$ $2^{\circ} \mathrm{C}$. Arrange the required number of pre-labeled Orochem DVB LP $30 \mathrm{mg} / 1 \mathrm{~mL}$ extraction cartridges on EZYPRESS $® 48$ - 48 Position Positive Pressure Processor. Condition the cartridges with $1.0 \mathrm{~mL}$ of methanol followed by 1.0 $\mathrm{mL}$ water. Load about $400 \mu \mathrm{L}$ of the prepared samples on conditioned cartridges carefully. Wash the cartridges with $1 \mathrm{~mL}$ of Water followed by $1 \mathrm{~mL}$ of Methanol in water, $10 \% \mathrm{v} / \mathrm{v}$; Dry the cartridges for 2 minutes by applying positive pressure at maximum flow rate or by applying full vacuum. Elute the contents from the cartridges with $1 \mathrm{~mL}$ of Methanol into pre-labeled tubes and vortex to mix. Transfer appropriate volume of samples into prelabeled Autosampler vials, and inject by using HPLC-ESI-MS/MS.

Pharmacokinetic Analysis: Single dosage pharmacokinetic parameters were calculated using
PK Solver tool from plasma drug concentrationtime data by non-compartmental methods. The maximum plasma concentration $\left(\mathrm{C}_{\max }\right)$ and time to maximum plasma concentration $\left(\mathrm{T}_{\max }\right)$ were obtained directly from the observed concentrationtime profiles. Linear trapezoidal rule was used to estimate the area under the plasma concentration versus time curve (AUC) from 0 to the last measurable concentration (AUC $0_{-}$). The area under the plasma concentration versus time curve from 0 to infinity (AUC $0_{-\infty}$ ) was calculated as AUC $0-t+C t / k e$, where $\mathrm{Ct}$ was the last measurable concentration. Ke was the elimination rate constant. The terminal elimination half-life $\left(t_{1 / 2}\right)$ was calculated as $0.693 / \mathrm{Ke}$.

\section{Validation:}

Specificity: A solution containing $2.0 \mathrm{ng} / \mathrm{ml}$ was injected on to the column under optimized chromatographic conditions to show the separation of Afatinib from impurities and plasma. The specificity of the method was checked for the interference from plasma.

Linearity: Spiked concentrations were plotted against peak area ratios of Afatinib to internal standard and the best fit line was calculated.Wide range calibration was determined by solutions containing $2 \mathrm{ng} / \mathrm{ml}-600 \mathrm{ng} / \mathrm{ml}$.

Recovery Studies: The \% mean recoveries were determined by measuring the responses of the extracted plasma Quality control samples at HQC, MQC and LQC against unextracted Quality control samples at HQC, MQC and LQC.

Precision and Accuracy: Intraday precision and accuracy was determined by analyzing quality control standards (6, 240 and $480 \mathrm{ng} / \mathrm{ml})$ and LLOQ Quality control standard $(2.00 \mathrm{ng} / \mathrm{mL})$ five times a day randomly, interday precision and accuracy was determined from the analysis of each quality control standards $(6,240$ and $480 \mathrm{ng} / \mathrm{ml})$ and LLOQ Quality Control standards $(2.00 \mathrm{ng} / \mathrm{mL})$ once on each of five different days.

Matrix Effect: The matrix effect for the intended method was assessed by using chromatographically screened human plasma. Concentrations equivalent to LQC and HQC of Afatinib were prepared with six different lots of plasma and are injected. 
RESULTS:

Results of Method Validation: The chromatography observed during the course of validation was acceptable and representative chromatograms of standard blank, HQC, MQC and LQC samples are shown in Fig. 1 - 4.

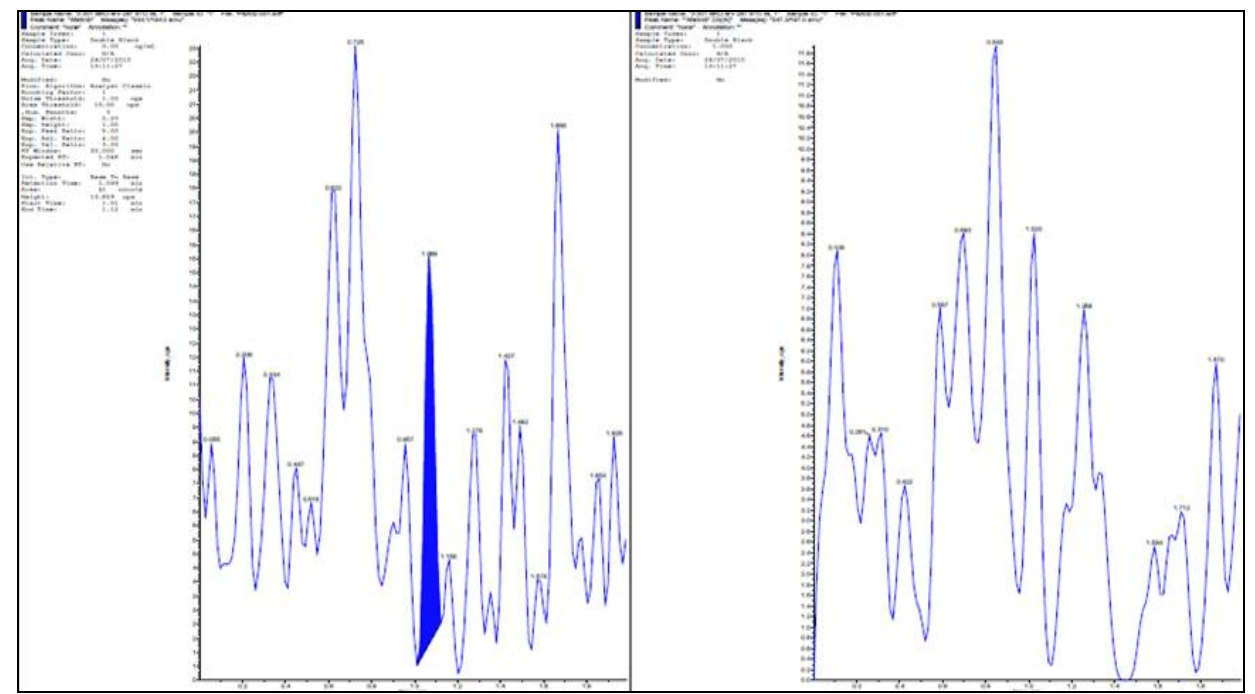

FIG. 1: REPRESENTATIVE BLANK CHROMATOGRAMS OF AFATINIB AND IS IN BLANK PLASMA

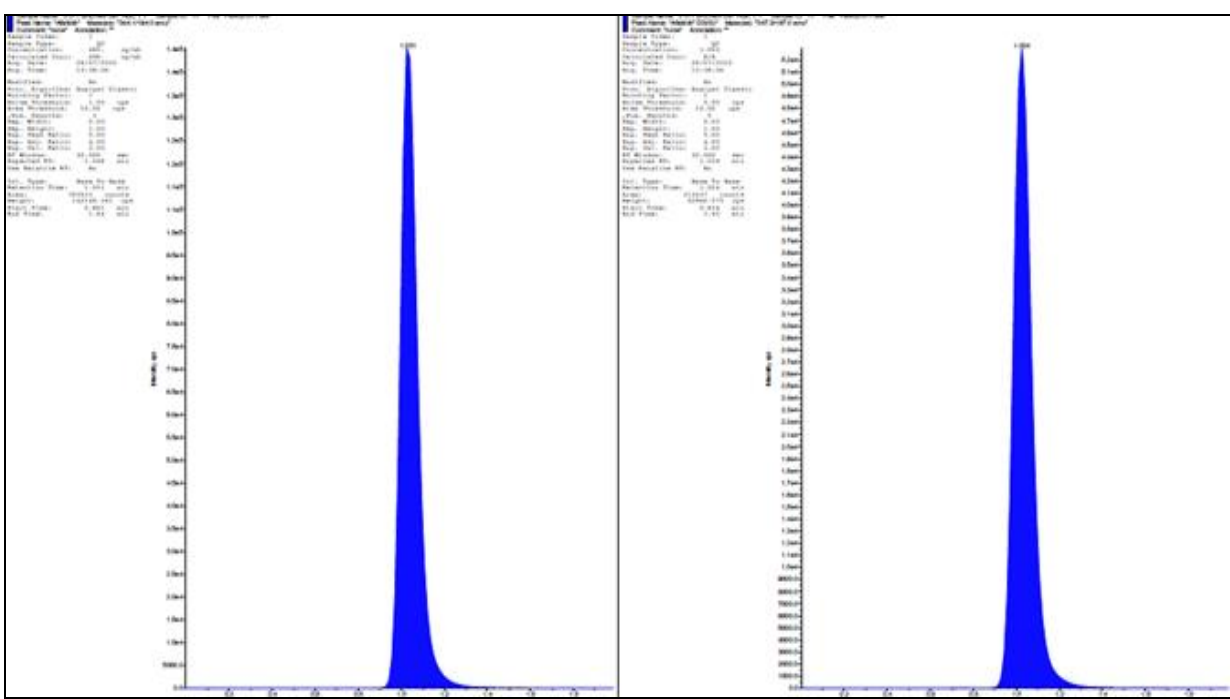

FIG. 2: REPRESENTATIVE HQC-CHROMATOGRAMS OF AFATINIB IN PLASMA WITH INTERNAL STANDARD

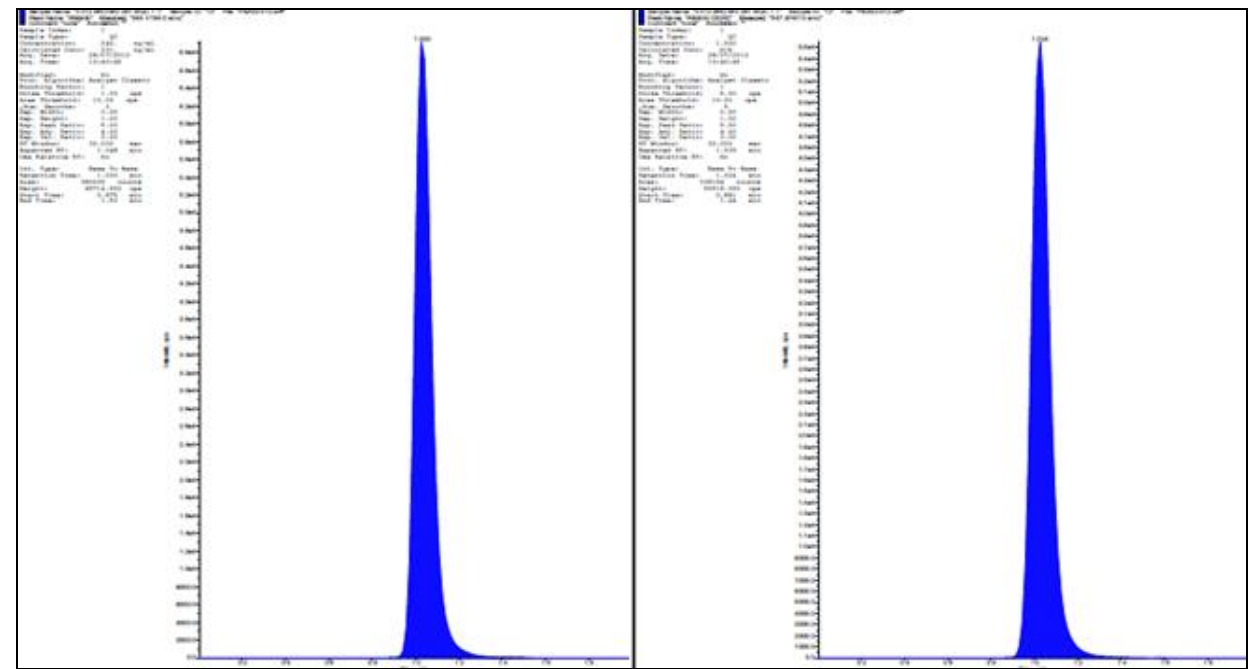

FIG. 3: REPRESENTATIVE MQC - CHROMATOGRAMS OF AFATINIB AND ITS INTERNAL STANDARD 


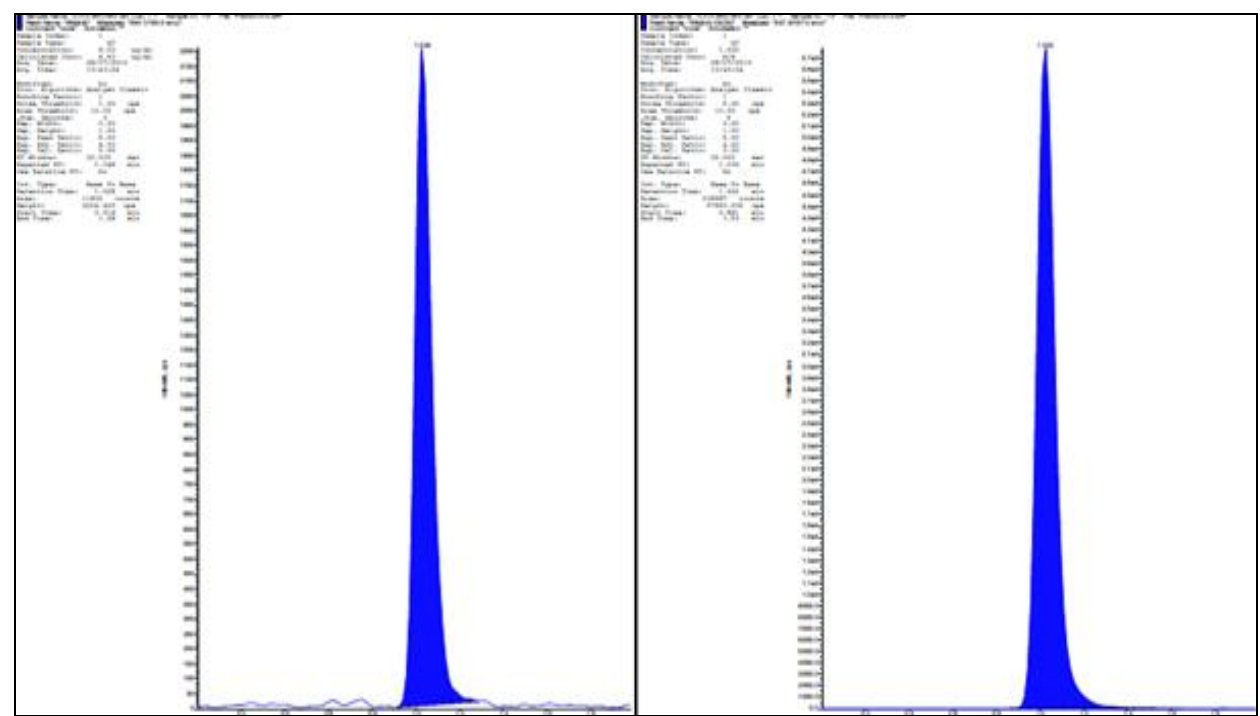

FIG. 4: REPRESENTATIVE CHROMATOGRAMS OF AFATINIB AND ITS INTERNAL STANDARD AT LQC LEVEL

The method developed was validated for linearity, calibration used for quantification by linear accuracy and precision, and stability as per ICH guidance $^{21-27}$. The results of validating parameters are given below.

Linearity: The three calibration curves (peak area ratio vs. Concentration) were linear over working range of $2 \mathrm{ng} / \mathrm{ml}$ to $600 \mathrm{ng} / \mathrm{ml}$ with eight point regression Fig. 5. The regression equation for the analysis was $\mathrm{Y}=0.0053 \mathrm{x}+0.0018$ with coefficient of correction $\left(\mathrm{r}^{2}\right)=0.9956$. The $\%$ bias and precision (\% CV) observed for the calibration curve standards was found to be -8.0 to 9.0 and $\leq$ 4.93 for Afatinib Table 1.

TABLE 1: LINEARITY STANDARDS OF AFATINIB

\begin{tabular}{|c|c|c|c|c|c|c|c|c|}
\hline & \multicolumn{8}{|c|}{ Afatinib } \\
\hline $\begin{array}{c}\text { STD ID } \\
\text { (in } \mathrm{ng} / \mathrm{mL})\end{array}$ & $\begin{array}{c}\text { STD 8 } \\
(2.0)\end{array}$ & $\begin{array}{c}\text { STD 7 } \\
(4.0)\end{array}$ & $\begin{array}{c}\text { STD 6 } \\
\text { (20) }\end{array}$ & $\begin{array}{c}\text { STD 5 } \\
(40)\end{array}$ & $\begin{array}{c}\text { STD } 4 \\
(80)\end{array}$ & $\begin{array}{c}\text { STD 3 } \\
(160)\end{array}$ & $\begin{array}{l}\text { STD 2 } \\
(300)\end{array}$ & $\begin{array}{c}\text { STD 1 } \\
(600)\end{array}$ \\
\hline $\mathrm{N}$ & \multicolumn{8}{|c|}{28} \\
\hline Mean & 1.96 & 4.09 & 21.8 & 42.8 & 79.7 & 156 & 288 & 552 \\
\hline SD & 0.0851 & 0.149 & 0.548 & 1.86 & 3.32 & 7.11 & 9.86 & 27.2 \\
\hline$\% \mathrm{CV}$ & 4.34 & 3.64 & 2.51 & 4.35 & 4.17 & 4.56 & 3.42 & 4.93 \\
\hline$\%$ Bias & -2.00 & 2.25 & 9.00 & 7.00 & -0.38 & -2.50 & -4.00 & -8.00 \\
\hline
\end{tabular}

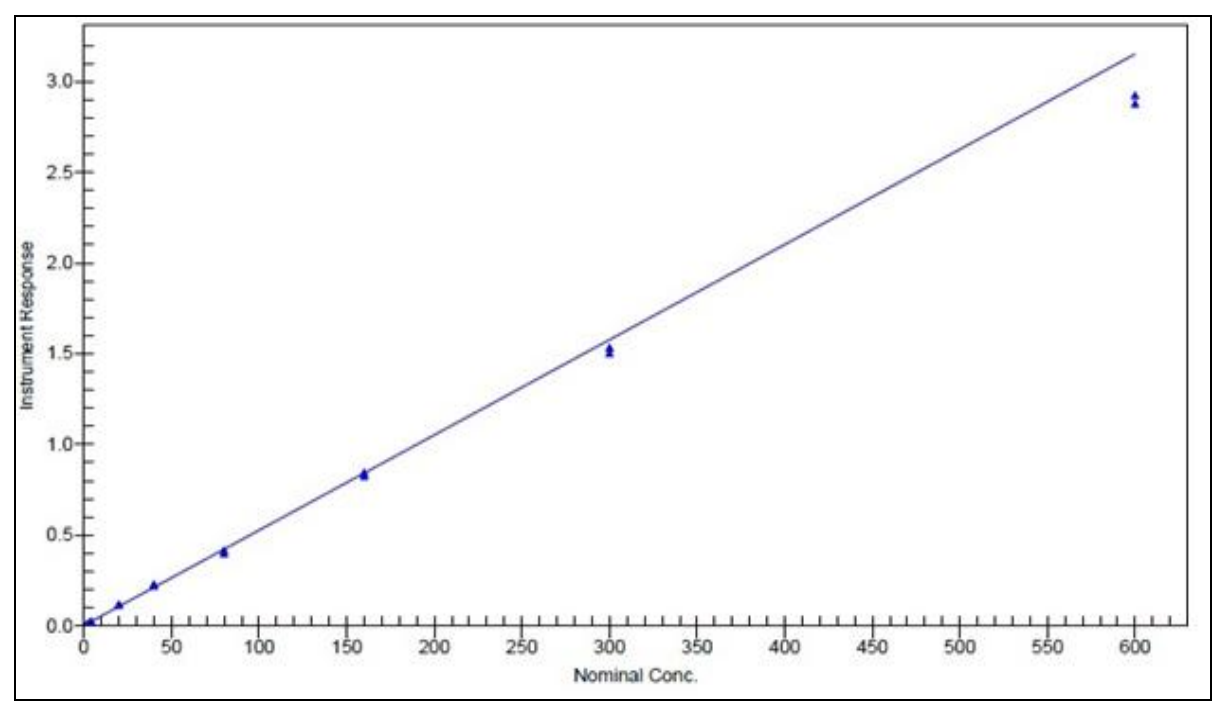

FIG. 5: SPIKED CONCENTRATIONS $(2 \mathrm{ng} / \mathrm{ml}-600 \mathrm{ng} / \mathrm{ml})$ WERE PLOTTED AGAINST PEAK AREA RATIO vs CONCENTRATION WITH NINE POINT CALIBRATION USED FOR QUANTIFICATION BY LINEAR REGRESSION 
Recovery: The \% mean recovery for Afatinib in LQC (6 ng/ml), MQC (240 ng/ml) and HQC (480 $\mathrm{ng} / \mathrm{ml})$ was $112.5 \%, \quad 113.1 \%$ and $112.7 \%$ respectively Table 2 .

TABLE 2: THE \% MEAN RECOVERY OF AFATINIB FOR LQC, MQC AND HQC

\begin{tabular}{|c|c|c|c|c|c|c|}
\hline \multirow[t]{2}{*}{ Replicate no. } & \multicolumn{2}{|c|}{ HQC } & \multicolumn{2}{|c|}{ MQC } & \multicolumn{2}{|c|}{ LQC } \\
\hline & $\begin{array}{c}\text { Extracted } \\
\text { Peak Area } \\
\text { Ratio }\end{array}$ & $\begin{array}{c}\text { Un-extracted } \\
\text { Peak Area } \\
\text { Ratio }\end{array}$ & $\begin{array}{c}\text { Extracted } \\
\text { Peak Area } \\
\text { Ratio }\end{array}$ & $\begin{array}{l}\text { Un-extracted } \\
\text { Peak Area } \\
\text { Ratio }\end{array}$ & $\begin{array}{c}\text { Extracted } \\
\text { Peak Area } \\
\text { Ratio }\end{array}$ & $\begin{array}{l}\text { Un-extracted } \\
\text { Peak Area } \\
\text { Ratio }\end{array}$ \\
\hline 1 & 2.176 & 2.160 & 1.133 & 1.118 & 0.027 & 0.027 \\
\hline 2 & 2.176 & 2.135 & 1.110 & 1.103 & 0.029 & 0.029 \\
\hline 3 & 2.186 & 2.119 & 1.111 & 1.115 & 0.032 & 0.033 \\
\hline 4 & 2.118 & 2.211 & 1.122 & 1.113 & 0.031 & 0.030 \\
\hline 5 & 2.127 & 2.140 & 1.090 & 1.086 & 0.027 & 0.027 \\
\hline Mean & 2.1566 & 2.1530 & 1.1132 & 1.1070 & 0.0292 & 0.0292 \\
\hline SD & 0.03156 & 0.03557 & 0.01599 & 0.01302 & 0.00228 & 0.00249 \\
\hline$\% \mathrm{CV}$ & 1.46 & 1.65 & 1.44 & 1.18 & 7.81 & 8.53 \\
\hline \% Mean Recovery & \multirow{2}{*}{\multicolumn{2}{|c|}{112.7}} & & 113.1 & & 112.5 \\
\hline \% Overall Recovery & & & \multicolumn{2}{|c|}{112.8} & & \\
\hline \% Overall CV & \multicolumn{6}{|c|}{0.3} \\
\hline
\end{tabular}

Intraday and Inter-day Precision: The mean intraday and inter-day precision of the method was found to be $1.31-5.16 \%$ for the quality control samples. This is within the acceptance limits of precision is $15 \%$. The limit of Quantification was found to be $2 \mathrm{ng} / \mathrm{ml}$. at such concentration the mean inter day and intraday precision was found to be $9.11 \%$ and $6.53 \%$ respectively. Which are within the acceptance limits of precision is $20 \%$ Table 3 .

TABLE 3: INTRA-DAY AND INTER-DAY QUALITY CONTROL SAMPLES FOR AFATINIB

\begin{tabular}{|c|c|c|c|c|}
\hline \multirow{2}{*}{$\begin{array}{c}\text { QC } \\
\text { Intra-batch }\end{array}$} & \multicolumn{4}{|c|}{ Afatinib (ng/mL) } \\
\hline & $\begin{array}{c}\text { LLOQ QC } \\
(2 \mathrm{ng} / \mathrm{mL})\end{array}$ & $\begin{array}{c}\text { LQC } \\
(6 \mathrm{ng} / \mathrm{mL}) \\
\end{array}$ & $\begin{array}{c}\text { MQC } \\
(240 \mathrm{ng} / \mathrm{mL})\end{array}$ & $\begin{array}{c}\text { HQC } \\
(480 \mathrm{ng} / \mathrm{mL})\end{array}$ \\
\hline Mean & 1.91 & 6.25 & 220.00 & 500.00 \\
\hline SD & 0.0841 & 0.239 & 2.88 & 7.09 \\
\hline$\% \mathrm{CV}$ & 4.40 & 3.82 & 1.31 & 1.42 \\
\hline$\%$ Bias & -4.50 & 4.17 & -8.33 & 4.17 \\
\hline Mean & 1.64 & 6.64 & 227.00 & 496.00 \\
\hline SD & 0.0851 & 0.222 & 4.30 & 6.80 \\
\hline$\% \mathrm{CV}$ & 5.19 & 3.34 & 1.89 & 1.37 \\
\hline$\%$ Bias & -18.00 & 10.67 & -5.42 & 3.33 \\
\hline Mean & 1.82 & 5.83 & 215 & 451 \\
\hline SD & 0.182 & 0.301 & 4.49 & 11.5 \\
\hline$\% \mathrm{CV}$ & 10.00 & 5.16 & 2.09 & 2.55 \\
\hline$\%$ Bias & -9.00 & -2.83 & -10.42 & -6.04 \\
\hline Inter-batch & $\begin{array}{c}\text { LLOQ QC } \\
(2 \mathrm{ng} / \mathrm{mL})\end{array}$ & $\begin{array}{c}\text { LQC } \\
(6 \mathrm{ng} / \mathrm{mL})\end{array}$ & $\begin{array}{c}\text { MQC } \\
(240 \mathrm{ng} / \mathrm{mL})\end{array}$ & $\begin{array}{c}\text { HQC } \\
(480 \mathrm{ng} / \mathrm{mL})\end{array}$ \\
\hline Mean & 1.79 & 6.24 & 221.00 & 482.00 \\
\hline SD & 0.163 & 0.418 & 6.23 & 24.30 \\
\hline$\% \mathrm{CV}$ & 9.11 & 6.70 & 2.82 & 5.04 \\
\hline$\%$ Bias & -10.50 & 4.00 & -7.92 & 0.42 \\
\hline
\end{tabular}

Matrix effect: The \% CV for HQC and LQC samples was observed $1.73 \%$ and $5.98 \%$ the acceptance criteria.

TABLE 4: MATRIX EFFECT OBTAINED WITH SIX DIFFERENT LOTS OF PLASMA

\begin{tabular}{ccc}
\hline QC ID & LQC & HQC \\
\hline Actual conc. & $\mathbf{6}(\mathbf{n g} / \mathbf{m L})($ area ratio) & $\mathbf{4 8 0}(\mathbf{n g} / \mathbf{m L})($ area ratio) \\
\hline 1 & 0.026 & 1.809 \\
2 & 0.028 & 1.893 \\
3 & 0.028 & 1.901 \\
\hline
\end{tabular}




\begin{tabular}{ccc}
\hline 4 & 0.028 & 1.863 \\
5 & 0.027 & 1.863 \\
6 & 0.031 & 1.869 \\
Mean & 0.0280 & 1.8663 \\
\pm SD & 0.00167 & 0.03234 \\
$\%$ CV & 5.98 & 1.73 \\
\hline
\end{tabular}

Results of Pharmacokinetic Studies: The trapezoidal rule. Afatinib showed $\mathrm{T}_{\max }$ of $3.833 \pm$ Pharmacokinetic parameter of afatinib was 0.752 and mean $\mathrm{C}_{\max }, \mathrm{AUC}_{0 \rightarrow \mathrm{t}}$ and $\mathrm{AUC}_{0 \rightarrow \alpha}$ for calculated from the plasma concentration-time Test formulation is $675.83 \pm 22.031,6213.417 \pm$ curves using pk solver software. Also, the area 257.922 and $6474.61 \pm 258.45$ respectively The under the plasma concentration-time curve from 0 results were presented in Table 5, Table 6 and Fig. to $48 \mathrm{hr}$ (AUC0-48) was calculated using 6.

TABLE 5: CALCULATED PLASMA CONCENTRATIONS IN RABBITS AT EACH TIME POINT

\begin{tabular}{ccccccccc}
\hline Time points in hours & \multicolumn{9}{c}{ Calculated concentrations (ng/ml) } \\
\hline & Rabbit 1 & Rabbit 2 & Rabbit 3 & Rabbit 4 & Rabbit 5 & Rabbit 6 & Avg & SD \\
\hline 0 & & 0 & 0 & 0 & 0 & 0 & 0 & 0 \\
0.5 & 16 & 18 & 19 & 12 & 15 & 18 & 16.33 & 2.58 \\
1 & 34 & 29 & 32 & 31 & 37 & 34 & 32.83 & 2.79 \\
1.5 & 52 & 58 & 60 & 58 & 52 & 56 & 56 & 3.35 \\
2 & 71 & 81 & 79 & 69 & 65 & 69 & 72.33 & 6.28 \\
2.5 & 84 & 96 & 91 & 87 & 93 & 89 & 90 & 4.29 \\
3 & 77 & 83 & 89 & 82 & 88 & 93 & 85.33 & 5.75 \\
4 & 68 & 75 & 76 & 70 & 76 & 81 & 74.33 & 4.68 \\
5 & 63 & 58 & 73 & 66 & 69 & 78 & 67.83 & 7.14 \\
6 & 58 & 54 & 64 & 62 & 62 & 67 & 61.17 & 4.58 \\
8 & 55 & 61 & 61 & 57 & 54 & 49 & 56.17 & 4.58 \\
12 & 52 & 56 & 57 & 49 & 47 & 41 & 50.33 & 5.99 \\
16 & 49 & 53 & 50 & 42 & 36 & 35 & 44.17 & 7.63 \\
24 & 46 & 49 & 45 & 40 & 33 & 32 & 40.83 & 7.08 \\
36 & 34 & 38 & 38 & 31 & 29 & 33 & 33.83 & 3.66 \\
48 & 0 & 0 & 0 & 0 & 0 & 0 & 0 & 0 \\
\hline
\end{tabular}

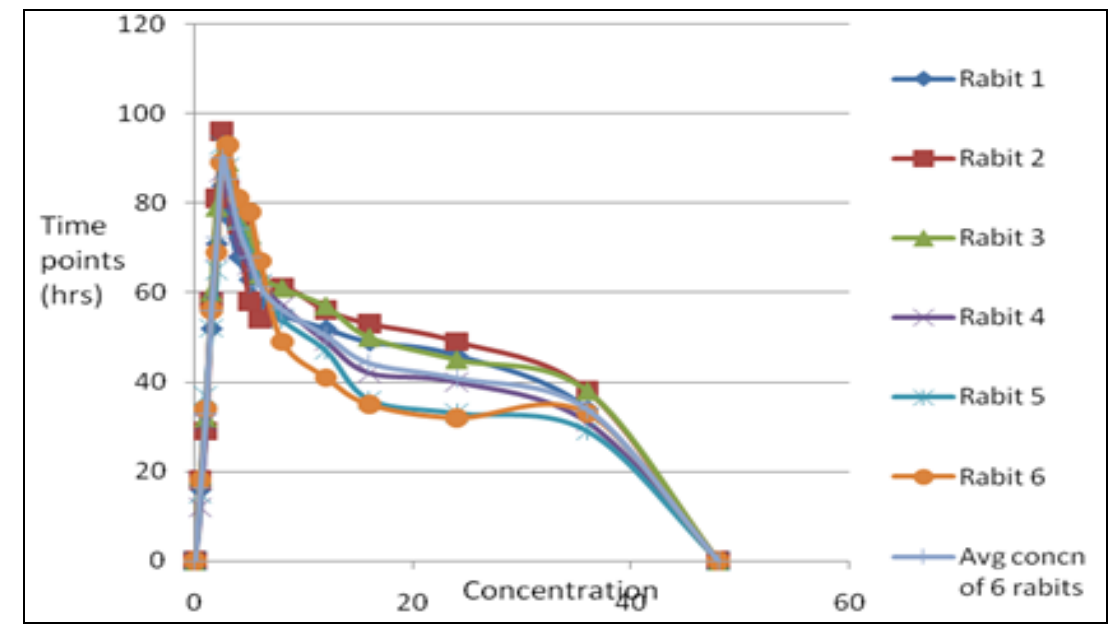

FIG. 6: PLASMA TIME PROFILE CURVES OF TEST ANIMALS

TABLE 6: CALCULATED MEAN VALUES OF PK PARAMETERS FOR TEST ANIMALS

\begin{tabular}{ccccccccc}
\hline Parameters & Rabbit 1 & Rabbit 2 & Rabbit 3 & Rabbit 4 & Rabbit 5 & Rabbit 6 & Mean & SD \\
\hline $\mathrm{C}_{\max }$ & 643 & 675 & 694 & 694 & 693 & 656 & 675.8 & 22 \\
$\log \mathrm{C}_{\max }$ & 2.808 & 2.829 & 2.8414 & 2.841 & 2.841 & 2.8169 & 2.83 & 0.01 \\
$\mathrm{~T}_{\max }$ & 3 & 4 & 5 & 4 & 4 & 3 & 3.833 & 0.75 \\
$\log \mathrm{T}_{\max }$ & 0.477 & 0.602 & 0.699 & 0.602 & 0.602 & 0.4771 & 0.577 & 0.09 \\
$\mathrm{t}_{1 / 2}$ & 8.331 & 9.563 & 6.7059 & 8.113 & 6.028 & 9.1414 & 7.98 & 1.37 \\
$\log \mathrm{t}_{1 / 2}$ & 0.921 & 0.981 & 0.8265 & 0.909 & 0.78 & 0.961 & 0.896 & 0.08 \\
\hline
\end{tabular}




\begin{tabular}{ccccccccc}
\hline Ke & 0.083 & 0.072 & 0.1033 & 0.085 & 0.115 & 0.0758 & 0.089 & 0.02 \\
$\log$ Ke & -1.08 & -1.14 & -0.986 & -1.068 & -0.94 & -1.12 & -1.06 & 0.08 \\
AUC0- & 5874 & 5940 & 6218 & 6455 & 6306 & 6488.5 & 6213 & 258 \\
log AUC 0- & 3.769 & 3.774 & 3.7937 & 3.81 & 3.8 & 3.8121 & 3.793 & 0.02 \\
AUC-0-inf_obc & 6150 & 6229 & 6469.5 & 6735 & 6471 & 6791.8 & 6475 & 258 \\
log AUC-0-inf_obc & 3.789 & 3.794 & 3.8109 & 3.828 & 3.811 & 3.832 & 3.811 & 0.02 \\
\hline
\end{tabular}

CONCLUSION: The bio-analytical methodology for determination of Afatinib described in this manuscript is highly specific, rugged and rapid for therapeutic drug monitoring both for analysis of routine samples of single dose or multiple dose pharmacokinetics and also for clinical trial samples with desired sensitivity, precision, accuracy and high throughput. The method involved a simple and specific sample preparation by solid phase extraction followed by isocratic chromatographic separation in $2.0 \mathrm{~min}$. The overall analysis time is promising compared to other reported procedures for Afatinib. The established LLOQ is sufficiently low to conduct a pharmacokinetic study with any marketing formulation of Afatinib in human volunteers.

ACKNOWLEDGEMENT: Authors are thankful to Dean and Head and co research scholars, faculty of pharmacy Mewar University, Chittorgarh, Rajasthan, India, for their constant encouragement and support for the completion of this work. Authors are also thankful to Central and departmental library of faculty of pharmacy and Mewar University, Chittorgarh, Rajasthan, India, for providing necessary books and journals.

CONFLICT OF INTEREST: We declare that we have no conflict of interest.

\section{REFERENCES:}

1. Li D, Ambrogio L, Shimamura T, et al.: BIBW2992, an irreversible EGFR/HER2 inhibitor highly effective in preclinical lung cancer models. Oncogene. 2008; 27: 470211.

2. Solca F, Dahl G, Zoephel A, et al.: Target binding properties and cellular activity of afatinib (BIBW 2992), an irreversible ErbB family blocker. J Pharmacol Exp Ther. 2012; 343: 342-50.

3. Hoffknecht P, Tufman A, Wehler T, Pelzer T, Wiewrodt R, Schütz M, Serke M, Stöhlmacher-Williams J, Märten A, Maria Huber $\mathrm{R}$ and Dickgreber $\mathrm{NJ}$; Afatinib Compassionate Use Consortium (ACUC). Efficacy of the irreversible ErbB family blocker afatinib in epidermal growth factor receptor (EGFR) tyrosine kinase inhibitor (TKI)-pretreated non-small-cell lung cancer patients with brain metastases or leptomeningeal disease. J Thorac Oncol. 2015; 10(1): 156-63.
4. Mukai H, Masuda N, Ishiguro H, et al.: Phase I trial of afatinib plus vinorelbine in Japanese patients with advanced solid tumors, including breast cancer. Cancer Chemother Pharmacol. 2015; 76: 739-50.

5. Reardon DA, Nabors LB, Mason WP, et al.: Phase I/randomized phase II study of afatinib, an irreversible ErbB family blocker, with or without protracted temozolomide in adults with recurrent glioblastoma. Neuro Oncol. 2015; 17: 430-439.

6. Ring A, Wheatley $\mathrm{D}$, Hatcher $\mathrm{H}$, et al:: Phase I study to assess the combination of afatinib with trastuzumab in patients with advanced or metastatic HER2-positive breast cancer. Clin Cancer Res. 2015; 21: 2737-2744.

7. Gordon MS, Springett GM, Su YB, et al:: A Phase I doseescalation study of afatinib combined with nintedanib in patients with advanced solid tumors. Future Oncol. 2015; 11: 1479-1491.

8. Boehringer I: Gilotrif [prescribing information] Boehringer Ingelheim Pharmaceuticals, Inc., Ridgefield, CT. http://www.gilotrif.com/. Accessed 7 Jun 2016.

9. European Medicines Agency. Giotrif: summary of product characteristics, version 24 May 2016. http://www. ema.europa.eu/docs/en_GB/document_library/EPAR__Product_Information/ human/002280/WC500152392.pdf. Accessed 7 Jun 2016.

10. European Medicines Agency. Committee for Medicinal Products for Human Use (CHMP) Assessment report for Giotrif (afatinib). 2013. http://www.ema.europa.eu/ docs/en_GB/document_library/EPARPublic_assessment_r eport/human/002280/WC5001523 94.pdf. Accessed 17 Mar 2016.

11. FDA Center for Drug Evaluation and Research. Afatinib pharmacology NDA\# 201292 review.2013.http://www. accessdata.fda.gov/drugsatfda_docs/nda/2013/201292Orig 1s000PharmR. pdf. Accessed 17 Mar 2016.

12. Eskens FA, Mom CH, Planting AS, et al.: A phase I dose escalation study of BIBW 2992, an irreversible dual inhibitor of epidermal growth factor receptor 1 (EGFR) and 2 (HER2) tyrosine kinase in a 2-week on, 2-week off schedule in patients with advanced solid tumours. Br J Cancer. 2008; 98: 80-5.

13. Yap TA, Vidal L, Adam J, et al.: Phase I trial of the irreversible EGFR and HER2 kinase inhibitor BIBW 2992 in patients with advanced solid tumors. J Clin Oncol. 2010; 28: 3965-72.

14. Marshall J, Hwang J, Eskens FA, et al.: A Phase I, openlabel, dose escalation study of afatinib, in a 3-week-on/1week-off schedule in patients with advanced solid tumors. Invest New Drugs. 2013; 31: 399-408.

15. Gordon MS, Mendelson DS, Gross M, et al:: A Phase I, openlabel, dose-escalation study of continuous once-daily oral treatment with afatinib in patients with advanced solid tumors. Invest New Drugs. 2013; 31: 409-16.

16. Molife LR, Rudman SM, Alam S, et al.: Phase II, openlabel trial to assess QTcF effects, pharmacokinetics and antitumor activity of afatinib in patients with relapsed or refractory solid tumors. Cancer Chemother Pharmacol. 2013; 72: 1213-22. 
17. Wind S, Schmid M, Erhardt J, et al.: Pharmacokinetics of afatinib, a selective irreversible ErbB family blocker, in patients with advanced solid tumours. Clin Pharmacokinet. 2013; 52: 1101-9.

18. Schnell D, Buschke S, Fuchs H, et al.: Pharmacokinetics of afatinib in subjects with mild or moderate hepatic impairment. Cancer Chemotherapy and Pharmacology. 2014; 74(2): 267-275.

19. Kadi AA, Abdelhameed AS, Darwish HW, Attwa MW and Al-Shakliah, NS: A highly efficient and sensitive LCMS/MS method for the determination of afatinib in human plasma: application to a metabolic stability study. Biomed. Chromatogr. 2016; 30:1248-55.

20. Hayashi H, Kita Y, Iihara H, Yanase K, Ohno Y, Hirose C, Yamada M, Todoroki K, Kitaichi K, Minatoguchi $\mathrm{S}$, Itoh $\mathrm{Y}$ and Sugiyama T: Simultaneous and rapid determination of gefitinib, erlotinib and afatinib plasma levels using liquid chromatography/tandem mass spectrometry in patients with non-small-cell lung cancer. Biomed. Chromatogr. 2016; 30: 1150-54.

21. Fouad M, Helvenstein $\mathbf{M}$ and Blankert B: Ultra High Performance Liquid Chromatography Method for the Determination of Two Recently FDA Approved TKIs in Human Plasma Using Diode Array Detection. Journal of Analytical Methods in Chemistry. 2015; 215128.
22. Sharma K, Giri K, Dhiman V, Dixit A, Zainuddin M and Mullangi R: A validated LC-MS/MS assay for simultaneous quantification of methotrexate and tofacitinib in rat plasma: application to a pharmacokinetic study. Biomedical Chromatography 2015; 29: 722-32.

23. Wu C, Xu X, Feng C, Shi Y, Liu W, Zhu X and Zhang J: Degradation kinetics study of cabozantinib by a novel stability-indicating LC method and identification of its major degradation products by LC/TOF-MS and LCMS/MS. J Pharm Biomed Anal. [Research Support, Non-U S Gov't]. 2014; 98: 356-63.

24. Wang X, Wang S, Lin F, Zhang Q, Chen H, Wang X, Wen $\mathrm{C}$, $\mathrm{Ma} \mathrm{J}$ and $\mathrm{Hu} \mathrm{L}$ : Pharmacokinetics and tissue distribution model of cabozantinib in rat determined by UPLC-MS/MS. J Chromatogr B. 2015; 983-984: 125-31.

25. Su Q, Li J, Ji X, Li J, Zhou T, Lu W and Li L: An LCMS/MS method for the quantitation of cabozantinib in rat plasma: Application to a pharmacokinetic study. J Chromatogr B. 2015; 985: 119-123.

26. ICH guidelines for the stability of new drug substances and products. Q1A (R2) ICH, Geneva; 2005; 1-13.

27. ICH guidelines for validation of analytical procedures: text and methodology. Q2 (R1) ICH, Geneva; 2005; 1-14.

\section{How to cite this article:}

Chandramowli B and Rajkamal BB: A validated LC-MS/MS method for pharmacokinetic study of afatinib in healthy rabbits. Int J Pharm Sci \& Res 2018; 9(3): 1120-28. doi: 10.13040/IJPSR.0975-8232.9(3).1120-28.

All @ 2013 are reserved by International Journal of Pharmaceutical Sciences and Research. This Journal licensed under a Creative Commons Attribution-NonCommercial-ShareAlike 3.0 Unported License.

This article can be downloaded to ANDROID OS based mobile. Scan QR Code using Code/Bar Scanner from your mobile. (Scanners are available on Google Playstore) 